\title{
Peningkatan Sikap Peduli Lingkungan dan Prestasi Belajar IPA menggunakan Model Problem Based Learning Berbasis Literasi pada Subtema Lingkungan Tempat Tinggalku di Kelas IV MI Muhammadiyah Kramat
}

\author{
Badarudin \\ Universitas Muhammadiyah Purwokerto, Indonesia \\ E-mail: badarudin@ump.ac.id
}

\begin{abstract}
Abstrak: Penelitian ini dilatarbelakangi masih rendahnya sikap peduli lingkungan dan prestasi belajar dalam proses pembelajaran IPA di kelas IV SD/MI. Tujuan penelitian ini adalah untuk mengetahui peningkatan sikap peduli lingkungan dan prestasi belajar IPA menggunakan model problem based learning $(P B L)$ berbasis literasi pada subtema lingkungan tempat tinggalku. Penelitian ini menggunakan metode kuasi eksperimen dengan desain Non equivalent (Pre-Test and PostTest) Control Groups Design. Subyek penelitian adalah siswa kelas IV pada MI Muhammadiyah Kramat, Kecamatan Kembaran, sebanyak 19 orang dan SDN 2 Sokaraja Tengah sebanyak 19 orang. Instrumen yang digunakan adalah angket sikap peduli lingkungan dan tes prestasi belajar IPA. Analisis data menggunakan uji Independent Sample t-test. Temuan dalam penelitian ini setiap indikator sikap peduli lingkungan dan prestasi belajar untuk kelompok eksperimen mendapatkan rerata gain lebih besar dari kelompok kontrol. Hasil penelitian menunjukkan (1) terdapat peningkatan sikap peduli lingkungan antara siswa yang memperoleh pembelajaran dengan model PBL berbasis literasi dan non-literasi, rerata gain untuk PBL berbasis literasi 7,73 dan non-literasi adalah 4,06. (2) terdapat peningkatan prestasi belajar IPA antara siswa yang memperoleh pembelajaran dengan model PBL berbasis literasi dan non-literasi, rerata gain untuk PBL berbasis literasi adalah 22,81 dan non-literasi adalah 13,51. Setiap tahapan dalam PBL berbasis literasi dapat memfasilitasi peningkatan sikap peduli lingkungan dan prestasi belajar IPA siswa kelas IV SD/MI
\end{abstract}

Kata Kunci: Sikap Peduli Lingkungan; Prestasi Belajar IPA; Problem Based Learning; Literasi.

\section{PENDAHULUAN}

Sekolah Dasar (SD) merupakan pondasi awal penanaman konsep dan tempat yang strategis dalam membentuk karakter siswa dalam pembentukan sikap dan keterampilan bagi siswa sehingga mampu bersaing, beretika, bermoral, sopan santun, memiliki sikap dan ketrampilan sebagai bekal untuk memasuki jenjang pendidikan selanjutnya. Lahirnya Peraturan Menteri Pendidikan dan Kebudayaan Nomor 23 Tahun 2015 tentang Penumbuhan Budi Pekerti, salah satunya, mengenai kegiatan membaca buku nonpelajaran selama lima belas menit sebelum waktu belajar dimulai. Kegiatan tersebut adalah upaya menumbuhkan kecintaan membaca kepada siswa dan pengalaman belajar yang menyenangkan sekaligus merangsang imajinasi. Gerakan Literasi Sekolah (GPS) merupakan sebuah upaya yang dilakukan secara menyeluruh untuk menjadikan sekolah sebagai organisasi pembelajaran yang warganya literat sepanjang hayat melalui pelibatan publik [1].

Salah satu bentuk penerapan GPS di SD adalah dengan mengenalkan siswa pada literasi bacaan tentang kepedulian terhadap llingkungan sekitar khusunya di daerah sekitar tempat tingggal. Ilmu Pengetahuan Alam (IPA) sebagai salah satu mata pelajaran yang diajarkan di SD yang] memberikan kesempatan kepada anak untuk mengembangkan kemampuan berpikirnya dalam menjelaskan suatu masalah dan melatihkan keterampilan [2]. Salah satu upaya untuk meningkatkan kualitas pendidikan IPA adalah melalui proses pembelajaran. Perlunya pengembangan model pembelajaran IPA yang mengarahkan pada aktivitas siswa dalam secara aktif mencari, mengolah, mengkonstruksi, dan menggunakan pengetahuan dari berbagai literasi bacaan diharapkan dapat membentuk sikap ilmiah dan kepedulian terhadap lingkungan sekitar.

Proses penyampaian pembelajaran IPA diharapkan memecahkan masalah lingkungan, serta menumbuh kembangkan kesadaran akan penanaman sikap peduli lingkungan pada siswa. Sikap peduli lingkungan merupakan contoh akhlak mulia yang identik dengan pembentukan watak atau karakter seseorang. Berdasarkan referensi [3] karakter adalah watak, tabiat, akhlak, atau kepribadian seseorang yang terbentuk dari hasil internalisasi berbagai kebajikan (virtues) yang diyakini dan digunakan sebagai landasan untuk cara pandang, berpikir, bersikap, dan bertindak. 
Berbagai penelitian tentang sikap peduli lingkungan yang sudah dilakukan. Misalnya berdasarkan referensi [4] penelitian tentang pengaruh penerapan pembelajaran Preview, Question, Read, Reflect, Recite and Review (PQ4R) terhadap hasil belajar IPS dan sikap peduli lingkungan siswa kelas V. Selain itu juga berdasarkan referensi [5] penelitian tentang determinan intensi perilaku pengelolaan sampah berkelanjutan pada siswa sekolah dasar.

Upaya dalam mewujudkan sikap peduli lingkungan salah satunya dengan proses pembelajaran yang mengarahkan siswa pada situasi belajar yang dapat mengembangkan pengetahuan, kemampuan berpikir dan keterampilan dalam memcahkan permasalahan lingkungan. Perlunya pemodelan dalam pembelajaran IPA yang mengarahkan pada aktivitas siswa dalam secara aktif mencari, mengolah, mengkonstruksi, dan menggunakan pengetahuan, perlu menjadi pertimbangan bagi guru dalam merumuskan sebuah pembelajaran IPA.

Sikap peduli lingkungan merupakan sikap menjaga lingkungan, mencegah dan memperbaiki kerusakan lingkungan. Berdasarkan hasil observasi dan informasi yang diperoleh dari guru kelas IV MI Muhammadiyah Kramat diperoleh data bahwa sikap peduli lingkungan siswa masih rendah. Sikap peduli lingkungan siswa rendah yang dibuktikan bahwa siswa kurang merawat tanaman di lingkungan sekolah, ditemukan sampah di laci-laci meja, dan siswa sering memanfaatkan kertas tidak sesuai peruntukkannya seperti untuk membuat mainan maupun tatakan makanan. Berdasarkan pemaparan di atas, maka sikap peduli lingkungan perlu dikenalkan dan diterapkan sejak dini sehingga diharapkan siswa memiliki kepedulian pada lingkungan dan alam sekitar.

Permasalahan lain yang ditemukan yaitu rendahnya prestasi belajar IPA. Berdasarkan keterangan guru kelas IV, diperoleh data bahwa hasil Penilaian Tegah Semester (PTS) semester I yaitu dari 20 siswa terdapat 2 siswa atau $10 \%$ mendapatkan nilai di atas kriteria ketuntasan minimal (KKM) untuk pengerjaan soal urain pemecahan masalah, sehingga untuk meningkatkan prestasi belajar siswa, guru melakukan kegiatan remidial. Siswa terbiasa menghafal materi sehingga siswa kurang memahami materi dengan baik, selain itu siswa enggan untuk menemukan informasi atau pokok-pokok penting dalam buku cetak atau sumber buku lain sehingga ketika diberi tugas mengerjakan LKS hasilnya masih belum maksimal karena ada beberapa soal yang tidak dikerjakan dengan alasan sulit padahal jawaban yang dicari ada pada buku cetak.

Berdasarkan pertimbangan dan hasil diskusi yang dilakukan dengan guru kelas IV maka peneliti menerapkan model problem based learning (PBL). PBL sebagai salah satu model pembelajaran yang bercirikan penggunaan masalah kehidupan nyata sebagai sesuatu yang harus dipelajari siswa. PBL adalah suatu pembelajaran yang menghadapkan siswa pada masalah autentik (nyata) sehingga diharapkan mereka dapat menyusun pengetahuannya sendiri, menumbuhkembangkan keterampilan tingkat tinggi dan inkuiri, memandirikan siswa, dan meningkatkan kepercayaan dirinya [6]. Tujuan PBL menurut [7] yaitu mengembangkan kemampuan berpikir kritis dan kemampuan pemecahan masalah dan sekaligus mengembangkan kemampuan peserta didik untuk secara aktif membangun pengetahuannya sendiri.

Berdasarkan permasalahan dan fenomena-fenomena yang telah dipaparkan sebelumnya, maka penulis tertarik untuk melaksanakan penelitian yang berjudul "Peningkatan Sikap Peduli Lingkungan dan Prestasi Belajar IPA Menggunakan Model Problem Based Learning Berbasis Literasi pada Subtema Lingkungan Tempat Tinggalku di Kelas IV MI Muhammadiyah Kramat”. Inovasi pada penelitian dilakukan adalah pembiasaan membaca sebelum pembelajaran dimulai dan pada saat kegiatan awal pembelajaran, kegiatan siswa selain melakukan presentasi di dalam kelas, juga melakukan aksi kepedulian terhadap lingkungan.

Perumusan masalah pada penelitian ini yaitu "Apakah terdapat Peningkatan Sikap Peduli Lingkungan dan Prestasi Belajar IPA Menggunakan Model Problem Based Learning Berbasis Literasi pada Subtema Lingkungan Tempat Tinggalku di Kelas IV MI Muhammadiyah Kramat?". Tujuan penelitian yang ingin dicapai adalah Mengkaji secara mendalam peningkatan sikap peduli lingkungan dan prestasi belajar antara siswa yang memperoleh pembelajaran dengan model PBL berbasis literasi dan non- literasi.

\section{METODE PENELITIAN}

Penelitian ini menggunakan metode kuasi eksperimen dengan desain Non equivalent [Pre-Test and Post-Test] Control Groups Design (NCGD). Dalam rancangan ini kelompok eksperimen (A) dan kelompok kontrol (B) pada dua kelompok tersebut, sama-sama dilakukan pretes dan postes hanya kelompok eksperimen saja yang di treatment [8]. Jadi dari dua kelompok penelitian yang ada yaitu kelompok eksperimen maupun kelompok kontrol dipilih tidak secara random, tetapi menerima keadaan subyek apa adanya. Kemudian kedua kelompok tersebut diberi pretest dan posttest. Kelompok eksperimen diberikan perlakuan dengan menggunakan model PBL berbasis literasi sedangkan kelompok kontrol pembelajaran berlangsung dalam situasi alamiah atau dalam penelitian ini disebut non-literasi.

Pemilihan sampel dengan menggunakan purposive sampling, yang mana sampel diambil secara sengaja sesuai dengan persyaratan sampel yang diperlukan. Pemilihan kelompok eksperimen dan kelompok kontrol langsung ditentukan oleh peneliti, dengan anggapan bahwa kedua kelompok tersebut memiliki karakteristik yang sama, dengan dasar pada awal pembagian kelas tidak didasarkan karakteristik tertentu. Dari hasil penentuan kelas yang akan dijadikan subjek penelitian antara kelompok eksperimen dan kelompok kontrol sama-sama mempelajari materi air. Data prestasi sebelum dilakukan penelitian untuk kedua kelompok selama ini sama. Berdasarkan data awal tersebut, pada penelitian ini sebagai sampel yang menjadi kelompok kontrol yaitu siswa kelas IV SDN 2 Sokaraja Tengah yang berjumlah 19 orang dan yang menjadi kelompok eksperimen yaitu kelas IV MI Muhammadiyah 
Kramat yang berjumlah 19 orang. Karakteristik sampel adalah siswa SD dengan usia 9 sampai 11 tahun anak mampu melakukan tindakan operatif, dan nalar logis menggantikan nalar intuitif sepanjang nalar tersebut bisa diterapkan pada contoh spesifik dan konkret [9]. Alasan pemilihan sekolah/madrasah yang dijadikan tempat dilaksanakannya penelitian adalah letak madrasah yang bersinggungan secara langsung dengan masyakat dan latar belakang sampel yang beragam.

Instrumen dalam penelitian ini terdiri dari seperangkat soal tes bentuk uraian yang mengukur prestasi belajar. Sedangkan instrumen dalam bentuk non tes berupa angket penelitian dengan menggunakan skala likert bentuk checklist untuk mengukur sikap peduli lingkungan siswa yang diberikan kepada siswa sebelum perlakukan (pretest) dan sesudah perlakukan (posttest). Instrumen non tes dikembangkan didasarkan pada indikator-indikator yang telah ditetapkan. Indikator-indikator sikap peduli lingkungan dalam penelitian ini adalah: (a) sikap hormat terhadap alam, (b) tanggung jawab terhadap alam, (c) solidaritas kosmis, (d) kasih sayang dan kepedulian terhadap alam, (e) tidak merugikan alam, dan (f) Hidup sederhana dan selaras dengan alam [10]. Instrumen non tes selajutnya berupa lembar observasi pelaksanaan pembelajaran dengan menggunakan model PBL dan perangkat pembelajaran yang dikembangkan dalam penelitian ini adalah Rencana Pelaksanaan Pembelajaran (RPP) yang mengikuti langkah-langkah pembelajaran dalam menggunakan model PBL.

Pengolahan data dalam penelitian ini ditujukan untuk menguji hipotesis yang diajukan. Data yang diperoleh dianalisis dengan menggunakan analisis statistik, analisis ini dilakukan dengan bantuan program software Microsoft Office Excel 2016, dan IBM SPSS for Statistic Ver.24.

\section{HASIL DAN PEMBAHASAN}

\section{Analsis Hasil Angket Sikap Peduli Lingkungan}

Perhitungan hasil angket sikap peduli lingkungan siswa dalam penelitian ini dilihat dari pencapaian siswa sebelum dan sesudah diberikan perlakuan. Adapun data sikap peduli lingkungan yang dianalisis meliputi, nilai pretes dan postes sikap peduli lingkungan. Selanjutnya berdasarkan nilai pretes dan postes tersebut ditentukan nilai gain-nya. Untuk menjawab rumusan masalah yang telah dikemukakan maka dilakukan analisis data berdasarkan gain yang diperoleh siswa. Tahapan pertama sebelum dilakukan analisis lebih lanjut adalah dengan melakukan uji normalitas dan uji homogenitas. Uji normalitas dan homogenitas ini merupakan uji prasyarat dalam menentukan uji yang akan digunakan selanjutnya, sehingga dapat ditentukan uji lanjutan yang akan digunakan dalam menganalisis data. Perhitungan terhadap gain ini dilakukan berdasarkan pada data nilai yang diperoleh dari kelompok eksperimen yang menggunakan PBL berbasis literasi serta kelompok kontrol yang mendapat pembelajaran tidak berbasis literasi. Berikut ini merupakan deskripsi hasil pretes, postes dan nilai gain sikap peduli lingkungan siswa kelompok eksperimen dan kelompok kontrol.
Tabel 1 Statistik Deskripsi Nilai Sikap Peduli Lingkungan

\begin{tabular}{cccccc}
\hline \multirow{2}{*}{ Nilai } & \multicolumn{5}{c}{ Eksperimen } \\
\cline { 2 - 6 } & $\mathbf{N}$ & $\mathbf{X}_{\min }$ & $\mathbf{X}_{\text {maks }}$ & $\boldsymbol{X}$ & $\mathbf{S}$ \\
\hline Pretes & 19 & 70,83 & 89,58 & 82,51 & 5,32 \\
Postes & 19 & 86,46 & 94,79 & 90,24 & 2,44 \\
Gain & 19 & 2,08 & 16,67 & 7,73 & 3,82 \\
Nilai & $\mathrm{N}$ & $\mathrm{X}_{\min }$ & $\mathrm{X}_{\text {maks }}$ & $X$ & $\mathrm{~S}$ \\
Pretes & 19 & 73,96 & 90,63 & 82,57 & 4,66 \\
Postes & 19 & 78,13 & 91,67 & 86,62 & 3,13 \\
Gain & 19 & 0,00 & 9,38 & 4,06 & 2,75 \\
\hline
\end{tabular}

Nilai Maksimum Ideal $=100$

Berdasarkan Tabel 1 di atas, diperoleh rerata nilai pretes kelompok eksperimen sebesar 82,51 dan kelompok kontrol 82,57 . Rerata pretes yang diperoleh kelompok eksperimen lebih rendah dibanding dengan rerata kelompok kontrol. Namun demikian rerata kedua kelompok tersebut terlihat berdekatan dengan selisih rerata 0,06 . Ini menunjukkan bahwa kemampuan kedua kelompok tersebut relatif sama sebelum diberikan perlakuan. Adapun untuk simpangan baku kelompok eksperimen 5,32 sedangkan simpangan baku untuk kelompok kontrol adalah 4,66. Ini menunjukkan data kelompok kontrol lebih menyebar dibanding dengan data kelompok eksperimen.

Selanjutnya dilihat dari rerata postes yang diperoleh oleh kelompok eksperimen sebesar 90,24 dengan simpangan baku 2,44 sedangkan rerata kelompok kontrol adalah 86,62 dengan simpangan baku 3,13. Hasil dari postes menunjukkan rerata yang diperoleh oleh kelompok eksperimen lebih tinggi dibanding dengan kelompok kontrol, dan untuk simpangan baku kelompok kontrol lebih menyebar dibanding kelompok eksperimen. Adapun untuk nilai rerata gain kelompok eksperimen sebesar 7,73 dan kelompok kontrol memperoleh nilai 4,06. Selisih rerata gain yang diperoleh kelompok eksperimen dibandingkan dengan kelompok kontrol adalah 3,67. Kedua kelompok mengalami peningkatan sikap peduli lingkungan. Apabila dibandingkan keduanya, kelompok eksperimen lebih tinggi dibandingkan kelompok kontrol. Untuk menjawab rumusan masalah dan hipotesis yang telah dikemukakan terhadap peningkatan sikap peduli lingkungan antara siswa yang memperoleh pembelajaran dengan model PBL berbasis literasi dan non- literasi, maka perlu dilakukan analisis lebih lanjut, terlebih dahulu dilakukan uji normalitas serta homogenitas terhadap nilai gain dari kedua kelompok tersebut.

Uji normalitas dilakukan dengan uji Shapiro-Wilk pada taraf siginifiaksi $\alpha=0,05$. Setelah dilakukan uji Shapiro-Wilk diperoleh nilai Sig. Kelompok eksperimen 0,715 dan kelompok kontrol 0,349. Adapun hasil pengujian descriptive statistik hasilnya sebagai berikut: 
Tabel 2

Uji Normalitas Nilai Gain Sikap Peduli Lingkungan

\begin{tabular}{lcccccc}
\hline \multirow{2}{*}{ Kelompok } & \multicolumn{3}{c}{ Kolmogorov-Smirnov $^{\boldsymbol{a}}$} & \multicolumn{3}{c}{ Shapiro-Wilk } \\
\cline { 2 - 7 } & Statistic & df & Sig. & Statistic & df & Sig. \\
\hline Eksperimen &, 087 & 19 &, $200^{*}$ &, 967 & 19 &, 715 \\
Kontrol &, 168 & 19 &, 164 &, 947 & 19 &, 349 \\
\hline
\end{tabular}

Taraf signifikasi pada $\alpha=0,05$

Berdasarkan uji Shapiro-Wilk pada Tabel 2 di atas, nilai sig. yang diperoleh kelompok eksperimen dan kontrol menunjukkan nilai lebih besar dari taraf signifikansi $\alpha=0,05$ yang menyebabkan $\mathrm{H}_{1}$ ditolak. Artinya $\mathrm{H}_{0}$ diterima. Jadi dapat disimpulkan bahwa nilai gain siswa kelompok eksperimen dan kontrol pada kelompok tinggi berdistribusi normal. Langkah selanjutnya dilakukan uji homogenitas terhadap nilai gain hasilnya dapat dilihat pada tabel berikut:

Tabel 3

Uji Homogenitas Nilai Gain Sikap Peduli Lingkungan Test of Homogeneity of Variances Sikap Peduli Lingkungan

\begin{tabular}{cccc}
\multicolumn{1}{l}{ Sikap Peduli Lingkungan } & & & \\
\hline Levene Statistic & df1 & df2 & Sig. \\
\hline 1.818 & 1 & 36 &, 186 \\
\hline
\end{tabular}

Taraf signifikasi pada $\alpha=0,05$

Nilai sig. yang diperoleh berdasarkan uji Homogeneity of Variance based on Mean dengan Levene Statistic pada Tabel 3 di atas adalah 0,186. Karena nilai sig yang diperoleh lebih besar dari taraf signifikansi yang telah ditetapkan yaitu $\alpha=0,05$, maka $\mathrm{H}_{0}$ diterima, dengan kata lain $\mathrm{H}_{1}$ ditolak. Sehingga dapat disimpulkan bahwa data nilai gain kelompok eksperimen dan kontrol bervariasi homogen.

Setelah dipastikan bahwa data nilai gain kedua kelompok berdistribusi normal dan bervariasi homogen, maka langkah selanjutnya melakukan uji perbedaan melalui Independent sampel t-tes terhadap nilai sikap peduli lingkungan siswa kelompok eksperimen dan kontrol yang dapat dilihat pada Tabel 4 berikut:

Tabel 4

Uji Perbedaan Nilai Gain Sikap Peduli Lingkungan

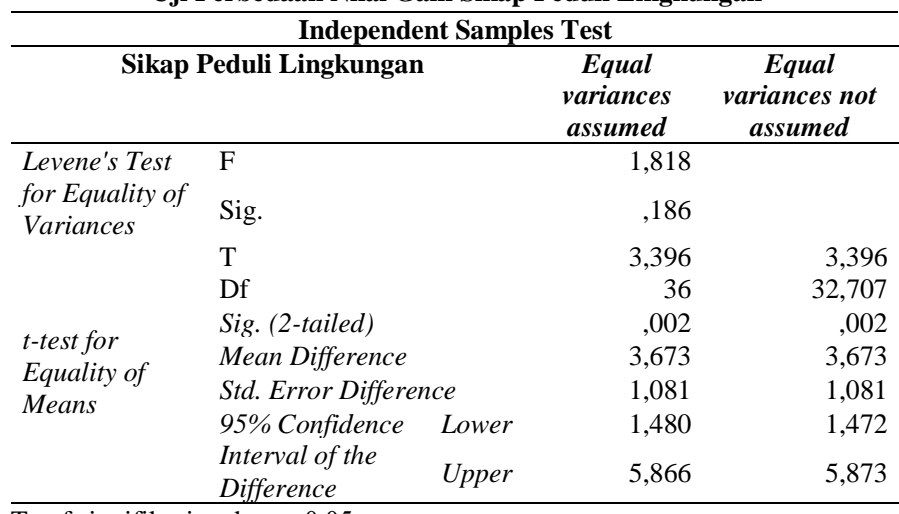

Taraf signifikasi pada $\alpha=0.05$

Dari Tabel 4 di atas, dapat diketahui bahwa untuk uji Independent sampel t-tes sikap peduli lingkungan memberikan nilai $\mathrm{t}$ hitung sebesar 3,396. Untuk $\alpha=0,05$, df $=36$ dan uji satu ekor, maka diperoleh nilai $\mathrm{t}_{\text {kritis }} 1,688$. Karena nilai $\mathrm{t}_{\text {hitung }}$ lebih besar dari $\mathrm{t}_{\text {kritis }}$ dan terletak di daerah penolakan $\mathrm{H}_{0}$, maka $\mathrm{H}_{1}$ diterima. Berdasarkan uji yang dilakukan maka hipotesis penelitian yang menyatakan sikap peduli lingkungan siswa yang belajar dengan model PBL berbasis literasi lebih baik dibanding dengan siswa yang belajar tidak menggunakan literasi dapat diterima. Artinya terdapat peningkatan sikap peduli lingkungan antara siswa yang memperoleh pembelajaran dengan model PBL berbasi literasi dan non literasi.

\section{Peningkatan Sikap Peduli Lingkungan}

Berdasarkan selisih rerata gain antara kelompok eksperimen dan kelompok kontrol adalah 3,67 atau 36,7\%. Apabila dibandingkan antara kedua model tersebut, peningkatan sikap peduli lingkungan secara signifikan terjadi pada kelompok eksperimen yang menerima pembelajaran PBL berbasis literasi.

Perhitungan gain tiap indikator sikap peduli lingkungan ini dilakukan berdasarkan pada data nilai yang diperoleh dari kelompok eksperimen yang menggunakan PBL berbasis literasi serta kelompok kontrol yang mendapat pembelajaran dengan model PBL non-literasi. Berikut disajikan tabel yang memperlihatkan hasil analisis deskriptif kuantitatif berupa rerata nilai pretes dan postes, standar deviasi (SD), serta rerata gain dalam persen (\%) untuk setiap indikator sikap peduli lingkungan, yaitu sebagai berikut:

Tabel 5

Rerata Nilai, Standar Deviasi, Gain pada Indikator Sikap Peduli Lingkungan untuk Kelompok Eksperimen dan Kontrol

\begin{tabular}{|c|c|c|c|c|c|c|c|c|c|c|c|}
\hline \multirow{3}{*}{ No } & \multirow{3}{*}{$\begin{array}{l}\text { Indikator } \\
\text { Sikap Peduli } \\
\text { Lingkungan }\end{array}$} & \multicolumn{5}{|c|}{ Kel. Eksperimen } & \multicolumn{5}{|c|}{ Kel Kontrol } \\
\hline & & \multicolumn{2}{|c|}{ Pretest } & \multicolumn{2}{|c|}{ Posttest } & \multirow[t]{2}{*}{$\begin{array}{l}\text { Gain } \\
(9 \%)\end{array}$} & \multicolumn{2}{|c|}{ Pretest } & \multicolumn{2}{|c|}{ Posttest } & \multirow[t]{2}{*}{$\begin{array}{l}\text { Gain } \\
(\%)\end{array}$} \\
\hline & & $\overline{\mathrm{x}}$ & SD & $\bar{x}$ & SD & & $\bar{x}$ & SD & $\overline{\mathrm{x}}$ & SD & \\
\hline 1 & 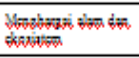 & $\begin{array}{l}82 . \\
89\end{array}$ & $\begin{array}{c}9.0 \\
4 \\
\end{array}$ & $\begin{array}{l}85 . \\
20\end{array}$ & $\begin{array}{c}6.6 \\
6 \\
\end{array}$ & 2.30 & $\begin{array}{l}83 . \\
55\end{array}$ & 8.13 & $\begin{array}{l}84 . \\
87\end{array}$ & $\begin{array}{c}7.0 \\
1 \\
\end{array}$ & 1.32 \\
\hline 2 & 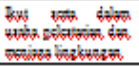 & $\begin{array}{l}83 . \\
55\end{array}$ & $\begin{array}{l}10 . \\
04\end{array}$ & $\begin{array}{l}91 . \\
78\end{array}$ & $\begin{array}{c}5.9 \\
1\end{array}$ & 8.22 & $\begin{array}{l}85 . \\
86\end{array}$ & 7.17 & $\begin{array}{l}89 . \\
14\end{array}$ & $\begin{array}{c}5.4 \\
5\end{array}$ & 3.29 \\
\hline 3 & 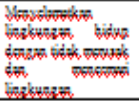 & $\begin{array}{l}82 . \\
89\end{array}$ & $\begin{array}{c}9.9 \\
6\end{array}$ & $\begin{array}{l}91 . \\
12\end{array}$ & $\begin{array}{c}6.0 \\
1\end{array}$ & 8.22 & $\begin{array}{l}80 . \\
59\end{array}$ & 8.56 & $\begin{array}{l}87 . \\
17\end{array}$ & $\begin{array}{c}6.7 \\
4\end{array}$ & 6.58 \\
\hline 4 & 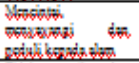 & $\begin{array}{l}87 . \\
83\end{array}$ & $\begin{array}{c}8.2 \\
0\end{array}$ & $\begin{array}{l}93 . \\
75\end{array}$ & $\begin{array}{c}5.5 \\
1 \\
\end{array}$ & 5.92 & $\begin{array}{l}86 . \\
84\end{array}$ & 6.55 & $\begin{array}{l}88 . \\
16\end{array}$ & $\begin{array}{c}5.4 \\
7 \\
\end{array}$ & 1.32 \\
\hline 5 & wis & $\begin{array}{l}67 . \\
76\end{array}$ & $\begin{array}{l}10 . \\
47\end{array}$ & $\begin{array}{l}86 . \\
18\end{array}$ & $\begin{array}{l}11 . \\
71\end{array}$ & $\begin{array}{c}18.4 \\
2\end{array}$ & $\begin{array}{l}71 . \\
05\end{array}$ & $\begin{array}{c}14.4 \\
7\end{array}$ & $\begin{array}{l}80 . \\
26\end{array}$ & $\begin{array}{l}10 . \\
47\end{array}$ & 9.21 \\
\hline 6 & Womplom & $\begin{array}{l}90 . \\
13 \\
\end{array}$ & $\begin{array}{l}13 . \\
55\end{array}$ & $\begin{array}{l}93 . \\
42 \\
\end{array}$ & $\begin{array}{c}8.7 \\
1\end{array}$ & 3.29 & $\begin{array}{l}87 . \\
50 \\
\end{array}$ & $\begin{array}{c}11.7 \\
9\end{array}$ & $\begin{array}{l}90 . \\
13 \\
\end{array}$ & $\begin{array}{c}6.6 \\
9\end{array}$ & 2.63 \\
\hline
\end{tabular}

Tabel 5 memperlihatkan pembelajaran IPA baik kelompok eksperimen dan kelompok kontrol semuanya menghasilkan rerata gain positif pada semua indikator sikap peduli lingkungan. Hal tersebut dapat membuktikan bahwa pembelajaran dengan menggunakan model PBL berbasis literasi dan non literasi dapat meningkatkan sikap peduli lingkungan. Perbedaan yang signifikan terdapat pada kelompok eksperimen yang memperoleh nilai rerata gain lebih tinggi dari kelompok kontrol.

Bila dicermati lebih lanjut, pada Tabel 5 terlihat bahwa setiap indikator sikap peduli lingkungan kelompok eksperimen mendapatkan rerata gain lebih tinggi dari kelompok kontrol. Persentase rerata nilai gain siswa pada setiap indikator sikap peduli lingkungan pada kelompok kontrol, rerata nilai gain terbesar $(9,21 \%)$ pada indikator Tidak merugikan dan mengancam eksistensi makhluk hidup di alam semesta dengan 
nilai rerata postes 80,26 . Pada kelompok eksperimen, rerata nilai gain terbesar $(18,42 \%)$ pada indikator Tidak merugikan dan mengancam eksistensi makhluk hidup di alam semesta, dengan nilai rerata postes 86,18. Berdasarkan Tabel 5 diperoleh kesimpulan kelompok eksperimen yang menerima pembelajaran dengan model PBL berbasis literasi selalu lebih baik dalam meningkatkan sikap peduli lingkungan dibandingkan kelompok kontrol yang menerima pembelajaran dengan model PBL non literasi.

Pembelajaran yang menerapkan model PBL ternyata memberikan kontribusi dalam meningkatkan sikap peduli lingkungan siswa. Melalui proses penyelidikan mandiri maupun kelompok, siswa dapat memahami permasalahan-permasalahan yang berkaitan dengan alam dan lingkungan. Berdasarkan referensi [6] menyebutkan bahwa PBL merupakan suatu model pembelajaran yang melibatkan siswa untuk menyelesaikan suatu masalah melalui tahap-tahapan metode ilmiah sehingga siswa dapat mempelajari pengetahuan yang berhubungan dengan masalah tersebut sekaligus memiliki keterampilan untuk menyelesaikan masalah. Melalui model pembelajaran PBL, siswa diajak untuk berpikir mengenai permasalahan tersebut misalnya penyebab permasalahan, dampak yang ditimbulkan serta solusi dari permasalahan tersebut sehingga dari ilmu yang diperoleh dari hasil pembelajaran siswa mulai menghindari halhal yang dapat merusak lingkungan serta memperbaiki kerusakan lingkungan.

\section{Analsis Hasil Tes Prestasi Belajar IPA}

Perhitungan hasil tes prestasi belajar siswa dalam penelitian ini dilihat dari pencapaian siswa sebelum dan sesudah diberikan perlakuan. Adapun data nilai prestasi belajar yang dianalisis meliputi, nilai pretes dan postes. Selanjutnya berdasarkan nilai pretes dan postes tersebut ditentukan nilai gain-nya. Untuk menjawab rumusan masalah yang telah dikemukakan maka dilakukan analisis data berdasarkan gain yang diperoleh siswa. Tahapan pertama sebelum dilakukan analisis lebih lanjut adalah dengan melakukan uji normalitas dan uji homogenitas. Uji normalitas dan homogenitas ini merupakan uji prasyarat dalam menentukan uji yang akan digunakan selanjutnya, sehingga dapat ditentukan uji lanjutan yang akan digunakan dalam menganalisis data. Perhitungan terhadap gain ini dilakukan berdasarkan pada data nilai yang diperoleh dari kelompok eksperimen yang menggunakan PBL berbasis literasi serta kelompok kontrol yang mendapat pembelajaran tidak berbasis literasi. Berikut ini merupakan deskripsi hasil pretes, postes dan nilai gain sikap peduli lingkungan siswa kelompok eksperimen dan kelompok kontrol.

Tabel 6

Statistik Deskripsi Nilai Prestasi Belajar IPA

\begin{tabular}{cccccc}
\hline \multirow{2}{*}{ Nilai } & \multicolumn{5}{c}{ Eksperimen } \\
\cline { 2 - 6 } & $\mathbf{N}$ & $\mathbf{X}_{\min }$ & $\mathbf{X}_{\text {maks }}$ & $\boldsymbol{x}$ & $\mathbf{S}$ \\
\hline Pretest & 19 & 33,33 & 63,33 & 47,89 & 9,76 \\
Posttest & 19 & 60,00 & 86,67 & 70,70 & 7,66 \\
Gain & 19 & 3,33 & 36,67 & 22,81 & 9,51 \\
Nilai & & & Kontrol & & \\
& $\mathrm{N}$ & $\mathrm{X}_{\min }$ & $\mathrm{X}_{\text {maks }}$ & $x$ & $\mathrm{~S}$ \\
Pretest & 19 & 33,33 & 63,33 & 48,07 & 9,83 \\
Posttest & 19 & 40,00 & 76,67 & 61,58 & 9,19 \\
Gain & 19 & 3,33 & 26,67 & 13,51 & 7,49 \\
\hline
\end{tabular}

Nilai Maksimum Ideal $=100$
Berdasarkan Tabel 6 di atas, diperoleh rerata nilai pretes kelompok eksperimen sebesar 47,89 dan kelompok kontrol 48,07 . Rerata pretes yang diperoleh kelompok eksperimen lebih rendah dibanding dengan rerata kelompok kontrol. Namun demikian rerata kedua kelompok tersebut terlihat berdekatan dengan selisih rerata 0,18 . Ini menunjukkan bahwa kemampuan kedua kelompok tersebut relatif sama sebelum diberikan perlakuan. Adapun untuk simpangan baku kelompok eksperimen 9,76 sedangkan simpangan baku untuk kelompok kontrol adalah 9,83. Ini menunjukkan data kelompok eksperimen lebih menyebar dibanding dengan data kelompok kontrol.

Selanjutnya dilihat dari rerata postes yang diperoleh oleh kelompok eksperimen sebesar 70,70 dengan simpangan baku 7,66 sedangkan rerata kelompok kontrol adalah 61,58 dengan simpangan baku 9,19. Hasil dari postes menunjukkan rerata yang diperoleh oleh kelompok eksperimen lebih tinggi dibanding dengan kelompok kontrol, dan untuk simpangan baku kelompok eksperimen lebih menyebar dibanding kelompok kontrol. Adapun untuk nilai rerata gain kelompok eksperimen sebesar 22,81 dan kelompok kontrol memperoleh nilai 13,51. Selisih rerata gain yang diperoleh kelompok eksperimen dibandingkan dengan kelompok kontrol adalah 9,30. Kedua kelompok mengalami peningkatan prestasi belajar. Apabila dibandingkan keduanya, kelompok eksperimen lebih tinggi dibandingkan kelompok kontrol. Untuk menjawab rumusan masalah dan hipotesis yang telah dikemukakan terhadap peningkatan prestasi belajar antara siswa yang memperoleh pembelajaran dengan model PBL berbasis literasi dan non- literasi, maka perlu dilakukan analisis lebih lanjut, terlebih dahulu dilakukan uji normalitas serta homogenitas terhadap nilai gain dari kedua kelompok tersebut.

Uji normalitas dilakukan dengan uji Shapiro-Wilk pada taraf siginifiaksi $\alpha=0,05$. Setelah dilakukan uji Shapiro-Wilk diperoleh nilai Sig. Kelompok eksperimen 0,158 dan kelompok kontrol 0,245. Adapun hasil pengujian descriptive statistik hasilnya sebagai berikut:

Tabel 7

Uji Normalitas Nilai Gain Prestasi Belajar IPA

\begin{tabular}{lcccrrrr}
\hline \multirow{2}{*}{ Kelompok } & \multicolumn{3}{c}{ Kolmogorov-Smirnov $^{\boldsymbol{a}}$} & \multicolumn{3}{c}{ Shapiro-Wilk } \\
\cline { 2 - 8 } & Statistic & df & Sig. & Statistic & df & Sig. \\
\hline Eksperimen &, 184 & 19 &, 090 &, 928 & 19 &, 158 \\
Kontrol &, 154 & 19 &, $200^{*}$ &, 938 & 19 &, 245 \\
\hline Taraf signifikasi pada $\alpha=0,05$ & & & & & &
\end{tabular}

Berdasarkan uji Shapiro-Wilk pada Tabel 7 di atas, nilai sig. yang diperoleh kelompok eksperimen dan kontrol menunjukkan nilai lebih besar dari taraf signifikansi $\alpha=0,05$ yang menyebabkan $\mathrm{H}_{1}$ ditolak. Artinya $\mathrm{H}_{0}$ diterima. Jadi dapat disimpulkan bahwa nilai gain siswa kelompok eksperimen dan kontrol pada kelompok tinggi berdistribusi normal. Langkah selanjutnya dilakukan uji homogenitas terhadap nilai gain hasilnya dapat dilihat pada Tabel 8 berikut: 
Tabel 8

Uji Homogenitas Nilai Gain Prestasi Belajar IPA Test of Homogeneity of Variances

\section{Prestasi Belajar}

\begin{tabular}{|c|c|c|c|c|}
\hline Levene Statistic & & & df 2 & Sig. \\
\hline & ,898 & 1 & 36 & 350 \\
\hline
\end{tabular}

Taraf signifikasi pada $\alpha=0,05$

Nilai sig. yang diperoleh berdasarkan uji Homogeneity of Variance based on Mean dengan Levene Statistic pada Tabel 8 di atas adalah 0,350. Karena nilai sig yang diperoleh lebih besar dari taraf signifikansi yang telah ditetapkan yaitu $\alpha=0,05$, maka $\mathrm{H}_{0}$ diterima, dengan kata lain $\mathrm{H}_{1}$ ditolak. Sehingga dapat disimpulkan bahwa data nilai gain kelompok eksperimen dan kontrol bervariasi homogen.

Setelah dipastikan bahwa data nilai gain kedua kelompok berdistribusi normal dan bervariasi homogen, maka langkah selanjutnya melakukan uji perbedaan melalui Independent sampel t-tes terhadap nilai prestasi belajar siswa kelompok eksperimen dan kontrol yang dapat dilihat pada Tabel 9 berikut:

Tabel 9

Uji Perbedaan Nilai Gain Prestasi Belajar IPA

\begin{tabular}{|c|c|c|c|c|}
\hline \multicolumn{5}{|c|}{ Independent Samples Test } \\
\hline \multicolumn{3}{|c|}{ Prestasi Belajar } & $\begin{array}{c}\text { Equal } \\
\text { variances } \\
\text { assumed }\end{array}$ & $\begin{array}{c}\text { Equal } \\
\text { variances not } \\
\text { assumed }\end{array}$ \\
\hline \multirow{3}{*}{$\begin{array}{l}\text { Levene's Test } \\
\text { for Equality } \\
\text { of Variances }\end{array}$} & $\mathrm{F}$ & &, 898 & \\
\hline & Sig. & &, 350 & \\
\hline & $\mathrm{T}$ & & 3,347 & 3,347 \\
\hline \multirow{6}{*}{$\begin{array}{l}\text { t-test for } \\
\text { Equality of } \\
\text { Means }\end{array}$} & Df & & 36 & 34,131 \\
\hline & Sig. (2-tailed) & & ,002 &, 002 \\
\hline & Mean Difference & & 9,298 & 9,298 \\
\hline & Std. Error Differ & & 2,778 & 2,778 \\
\hline & $95 \%$ Confidence & Lower & 3,664 & 3,653 \\
\hline & $\begin{array}{l}\text { Interval of the } \\
\text { Difference }\end{array}$ & Upper & 14,932 & 14,943 \\
\hline
\end{tabular}

Taraf signifikasi pada $\alpha=0.05$

Dari Tabel 9 di atas, dapat diketahui bahwa untuk uji Independent sampel t-tes prestasi belajar memberikan nilai $\mathrm{t}$ hitung sebesar 3,347. Untuk $\alpha=0,05$, df $=36$ dan uji satu ekor, maka diperoleh nilai $t_{\text {kritis }} 1,688$. Karena nilai $t$ hitung lebih besar dari $\mathrm{t}$ kritis dan terletak di daerah penolakan $\mathrm{H}_{0}$, maka $\mathrm{H}_{1}$ diterima. Berdasarkan uji yang dilakukan maka hipotesis penelitian yang menyatakan prestasi belajar siswa yang belajar dengan model PBL berbasis literasi lebih baik dibanding dengan siswa yang belajar tidak menggunakan literasi dapat diterima. Artinya terdapat peningkatan prestasi belajar antara siswa yang memperoleh pembelajaran dengan model PBL berbasis literasi dan non literasi.

4. Peningkatan Prestasi Belajar IPA

Nilai prestasi belajar dalam penelitian ini diperoleh berdasarkan hasil pelaksanaan pretes yang dilakukan sebelum pembelajaran dan postes setelah pembelajaran untuk kedua kelompok (eksperimen dan kontrol) peningkatan prestasi belajar untuk kedua kelompok diperleh dari selisih nilai postes dengan nilai pretes yang dilakukan diakhir kegiatan pembelajaran. Mulyasa (2014: 189) menyatakan bahwa prestasi belajar adalah hasil yang diperoleh seseorang setelah menempuh kegiatan belajar, sedangkan belajar pada hakekatnya merupakan usaha sadar yang dilakukan seseorang untuk memenuhi kebutuhannya. Berikut ini adalah rekapitulasi nilai siswa dapat dilihat pada Tabel 10 di bawah ini:

Tabel 10

Rekapitulasi Nilai Prestasi Belajar IPA untuk Kelompok Eksperimen dan Kontrol

\begin{tabular}{cccc}
\multicolumn{2}{c}{ Kelompok Eksperimen dan Kontrol } \\
\cline { 2 - 4 } Keterangan & Pretes & Posttest & Gain \\
\cline { 2 - 4 } & 47,89 & 70,70 & 22,81 \\
Rata-rata & 63,33 & 86,67 & 36,67 \\
Nilai Maksimal & 33,33 & 60,00 & 3,33 \\
Nilai Minimal & 0 & 4 & \\
Siswa Tuntas & 19 & 15 & \\
Siswa Tidak Tuntas & $0 \%$ & $21,05 \%$ & \\
Ketuntasan Klasikal (\%) & \multicolumn{3}{c}{ Kelompok Kontrol } \\
Rata-rata & 48,07 & 61,58 & 13,51 \\
Nilai Maksimal & 63,33 & 76,67 & 26,67 \\
Nilai Minimal & 33,33 & 40,00 & 3,33 \\
Siswa Tuntas & 0 & 1 & \\
Siswa Tidak Tuntas & 19 & 18 & \\
Ketuntasan Klasikal $(\%)$ & $0 \%$ & $5,26 \%$ &
\end{tabular}

Tabel 10 memperlihatkan pembelajaran IPA baik kelompok eksperimen dan kelompok kontrol semuanya menghasilkan rerata gain positif. Hal tersebut dapat membuktikan bahwa pembelajaran dengan menggunakan model PBL berbasis literasi dan non literasi dapat meningkatkan prestasi belajar IPA. Perbedaan yang signifikan terdapat pada kelompok eksperimen yang memperoleh nilai rerata gain lebih tinggi dari kelompok kontrol.

Ditinjau dari tingkat ketuntasan, dimana belajar dikatakan tuntas apabila siswa telah menguasai $75 \%$ materi, maka tingkat ketuntasan belajar dari hasil postes kelompok eksperimen $21,05 \%$ (kategori belum tuntas) dan untuk kelompok kontrol $5,26 \%$ (kategori belum tuntas). Apabila ditinjau dari tingkat ketuntasan individual yang dicapai kedua kelompok, maka diperoleh data siswa yang menguasai materi $75 \%$ ke atas ada 4 dari 19 siswa untuk kelompok eksperimen dan 1 dari 19 siswa untuk kelompok kontrol.

Berdasarkan hasil analisis nilai pretes, dan wawancara dengan guru serta perwakilan siswa, diperoleh keterangan bahwa siswa kedua kelas mengalami kesulitan dalam mengerjakan soal prestasi belajar berbentuk urain pemecahan masalah dikarenakan siswa jarang dilatihkan mengerjakan soalsoal berbentuk uraian yang memerlukan proses berpikir tinggi, sehingga rata-rata jawaban siswa tidak sesuai dengan yang diperintahkan dalam soal. Selama ini siswa diberikan soal berdasarkan soal yang terdapat pada buku pegangan siswa yang berbentuk pilihan ganda dan isian singkat. Siswa masih kesulitan dalam menjawab soal bentuk uraian karena jawaban siswa masih bentuk jawaban singkat, tidak diuraikan.

Bila dicermati lebih lanjut, pada Tabel 10 terlihat bahwa model PBL berbasis literasi dan non literasi dapat meningkatkan prestasi belajar siswa kelas IV subtema lingkungan tempat tinggalku. Hal tersebut diperkuat oleh Inel dan Ali (2010), dalam artikelnya bahwa "problem-based learning method in science and technology teaching is more effective in enhancing students' academic achievement" yang berarti pembelajaran berbasis masalah dalam pengajaran teknologi dan sains lebih efektif dalam meningkatkan prestasi akademik siswa. Siswa dilatih untuk memahami materi melalui 
permasalahan-permasalahan sehingga siswa tidak hanya mengingat tetapi mampu memahami materi dengan baik.

\section{SIMPULAN DAN SARAN}

Simpulan dari penelitian ini adalah sebagai berikut: (1) Terdapat peningkatan sikap peduli lingkungan antara siswa yang memperoleh pembelajaran dengan model PBL berbasis literasi dan non literasi. Model PBL berbasis literasi lebih meningkatkan sikap peduli lingkungan dibandingkan dengan model PBL non literasi. Hal ini dapat dilihat dari rerata gain untuk kelompok eksperimen 7,73 atau 77,3\% dan kelompok kontrol 4,06 atau 40,6\%. (2) Terdapat peningkatan prestasi belajar antara siswa yang memperoleh pembelajaran dengan model PBL berbasis literasi dan non literasi. Model PBL berbasis literasi lebih meningkatkan prestasi belajar dibandingkan dengan model PBL non literasi. Hal ini dapat dilihat dari rerata gain untuk kelompok eksperimen 22,81 dan kelompok kontrol 13,51.

Beberapa saran yang dapat dipertimbangkan untuk pembelajaran selanjutnya, diantaranya: (1) Berdasarkan hasil penelitian, diketahui bahwa secara keseluruhan pembelajaran dengan model PBL berbasis literasi memberikan pengaruh yang positif dan lebih baik dalam mengembangkan sikap peduli lingkungan dan prestasi belajar IPA siswa kelas IV di SD/MI, khususnya di SD/MI tempat penelitian. Untuk itu pembaca dapat mengembangkan penelitian lain yang sejenis atau yang dianggap lebih baik, tentunya dengan model lain dan kemampuan IPA lainnya serta pada jumlah sampel yang lebih besar.(2) Apabila dilihat dari tingkat ketuntasan belajar dan nilai prestasi belajar, guru perlu membiasakan siswa dilatih mengerjakan soal-soal bentuk uraian yang memerlukan proses berpikir tinggi. (3) Hasil penelitian ini dapat dilanjutkan dan dikembangkan lebih mendalam lagi oleh pembaca, dalam rangka mencari solusi terbaik dalam pembelajaran IPA agar lebih baik lagi.

\section{DAFTAR PUSTAKA}

[1] Faizah, dkk. (2016). Panduan Gerakan Literasi Sekolah di Sekolah Dasar. Jakarta: Direktorat Pembinaan SD. DirjenDikdasmen. Kemdikbud.

[2] Samatowa, U. (2010). Pembelajaran IPA di Sekolah Dasar. Jakarta: PT. Indeks.

[3] Hamid, S. H., dkk. (2010). Bahan Pelatihan: Penguatan Metodologi Pembelajaran Berdasarkan Nilai-nilai Budaya untuk Membentu Daya Saing dan Karakter Bangsa. Jakarta: Kemdiknas. BPP. Pusat Kurikulum.

[4] Pramana, K. A. B., Lasmawan, I. W., \& Marhaeni, A. A. I. N. (2014) Pengaruh Penerapan Pembelajaran PQ4R Kontekstual Terhadap Hasil Belajar IPS dan Sikap Peduli Lingkungan Siswa Kelas V. e-Journal Program Pascasarjana Universitas Pendidikan Ganesha, Program Studi Pendidikan Dasar. Volume 4 Tahun 2014

[5] Gusti, A, dkk. (2015). Determinan Intensi Perilaku Pengelolaan Sampah Berkelanjutan pada Siswa Sekolah Dasar. Jurnal Kesehatan Masyarakat Andalas. e-ISSN 2442-6725. April 2015 - September 2015 | Vol. 9, No. 2 Hal. 65-72 Tersedia: http://jurnal. m.unand.ac.id/index.php/jkma/ diakses: 11 Juni 2018.

[6] Arends. I. R. (2008). Learning To Teach. Yogyakarta: Pustaka Belajar

[7] Hosnan, M. (2014). Pendekatan Saintifik dan Kontekstual dalam Pembelajaran Abad 21. Kunci Sukses Implementasi Kurikulum 2013. Bogor: Ghalia Indonesia.

[8] Creswell, J. W. (2010). Research Design, Pendekatan Kualitatif, Kuantitatif, dan Mixed. Penerjemah: Fawaid, A. Yogyakarta: Pustaka Pelajar.

[9] Santrock, J. H. (2007). Child Development; Perkembangan Anak. (Edisi Kesebelas, Jilid 1). Penerjemah: Rachmawati, M. \& Kuswanti, A. Jakarta: Penerbit Erlangga.

[10] Keraf, A. S. (2010). Etika Lingkungan Hidup. Jakarta: PT. Kompas Media Nusantara. 